\title{
Effects of close cutting on ground cover and quality of a polystand of Manilagrass and cool season turfgrasses
}

\author{
Nicola Grossi, ${ }^{1}$ Marco Fontanelli, ${ }^{1}$ Christian Frasconi, ${ }^{1}$ Luisa Martelloni, ${ }^{1}$ Michele Raffaelli, ${ }^{1}$ \\ Andrea Peruzzi, ${ }^{1}$ Monica Gaetani, ${ }^{1}$ Simone Magni, ${ }^{1}$ Lisa Caturegli, ${ }^{2}$ Marco Volterrani, ${ }^{1}$ \\ Michel Pirchio ${ }^{1}$
}

${ }^{1}$ Department of Agriculture, Food and Environment, University of Pisa; ${ }^{2}$ Department of Agricultural and Food Sciences, University of Bologna, Italy

\begin{abstract}
Warm season turfgrasses can be grown successfully in the transition zone, but dormancy occurs to some extent during the winter. Overseeding with cool-season turfgrasses is necessary if winter dormancy of warm season turfgrasses is not tolerated. The increasing availability of zoysiagrass cultivars has enabled this genus to be considered suitable for low-maintenance golf courses, especially for golf tees and golf fairways. On the other hand, zoysiagrasses have the most rigid leaves of all turfgrass species, followed by bermudagrasses and by the other warm season turf species. Thus, to have a high mowing quality, mowers working constantly on zoysiagrasses require more sharpening than mowers working on other grasses. Rotary mowers are not suitable for mowing at low heights and often result in scalping, while reel mowers perform optimal mowing at a short height (below $2.5 \mathrm{~cm}$ ) but require accurate management and frequent sharpening. Autonomous mowers have proven to produce a superior turf quality compared with traditional walk-behind rotary mowers, but no autonomous mower has ever been tested at a low mowing height
\end{abstract}

Correspondence: Nicola Grossi, Department of Agriculture, Food and Environment, University of Pisa, via del Borghetto 80, 56124 Pisa, Italy.

Tel.: +39.050.2218928. E-mail: nicola.grossi@unipi.it

Key words: Festuca rubra ssp; Lolium spp; Poa spp; shoot density; Trifolium repens; Zoysia matrella; autonomous mower.

Acknowledgements: we sincerely thank FERCAD S.p.a. Company (Altavilla Vicentina, Vicenza, Italy) for providing the autonomous mower and GIMAS s.r.l. Company (Merano, Italy) for providing the seeds of the cool season species. We did not receive funds for this research.

Received for publication: 19 December 2018.

Revision received: 11 February 2019.

Accepted for publication: 21 February 2019.

CCopyright N. Grossi et al., 2019

Licensee PAGEPress, Italy

Italian Journal of Agronomy 2019; 14:1378

doi:10.4081/ija.2019.1378

This article is distributed under the terms of the Creative Commons Attribution Noncommercial License (by-nc 4.0) which permits any noncommercial use, distribution, and reproduction in any medium, provided the original author(s) and source are credited. on an overseeded warm season turfgrass. Because of this, the trial was carried out to simulate a golf tee overseeded with cool season turfgrasses, with low input fertilisation rates and with one of the most difficult turf species to mow; i.e. Zoysia matrella (L.) Merr. The trial was carried out in San Piero a Grado (Pisa, Italy) from October 2016 to October 2018. After a two-year period the best turf quality was achieved with Festuca rubra L. ssp. cultivars among the overseeded species, especially during fall. In many cases turf quality increased after manila grass green up since the combination of both cool season and warm season species gave a higher quality to the turfgrass, due to the finer leaf texture and higher shoot density of some cool season species. Moreover, recovery of manila grass ground cover was satisficing. In conclusion, a polystand of manila grass and Festuca rubra ssp. could be suitable for golf tees with low-input management.

\section{Introduction}

The use of warm season turfgrass species in hot and transitional climatic zones can give numerous advantages over cool season turfgrass species, such as lower water needs, the possibility of irrigating with salty water or wastewater (Carrow and Duncan, 1988; Harivandi, 1991) and lower susceptibility to fungal diseases (Gullino et al., 2000). Considerable technical and environmental advantages could be gained, by a more widespread utilisation of warm season turfgrasses in the coastal regions of the Mediterranean Basin. This area falls in the turfgrass transition zone, where warm season turfgrasses can be grown successfully, but dormancy occurs to some extent during the cooler months (Volterrani et al., 1997). Where winter quiescence of warm season turfgrasses is not tolerated for technical or aesthetic reasons, overseeding with cool season turfgrasses is necessary in order to remedy. This practice allows to create a temporary actively growing green cover, when the use of turf covers or turf painting are considered secondary remedies to warm season turfgrass winter dormancy (Volterrani et al., 2003). The increasing popularity and availability of zoysiagrass cultivars has enabled this genus to be considered suitable for sports turfs and golf courses (Magni et al., 2017; Patton et al., 2017). Zoysia spp. have a good tolerance to moisture deficits and shade, produce limited vertical growth requiring minimal mowing, develop a dense mat of vertical and horizontal organs that limit weed invasion and have a short dormant period, making them potentially suitable for low-maintenance turfs (Whereley et al., 2011; Pompeiano et al., 2012; Pompeiano et al., 2014). Historically, zoysiagrass cultivars were developed for lawn use; however they have a high genetic variability, which results in several morphological differences 
(Anderson, 2000). Although the use of zoysiagrasses on putting greens in the United States is quite recent (Morris, 2016), the use of zoysiagrasses for golf greens, golf tees and golf fairways is encouraging (Engelke et al., 2002a, 2002b). The optimal mowing height for zoysiagrasses ranges from 0.3 to $6.4 \mathrm{~cm}$ (Patton et al., 2017), depending on species and cultivars. On the other hand, zoysiagrasses have the most rigid leaves of all turfgrass species, followed by bermudagrasses and by the other warm season turf species (Turgeon, 2012). High neutral detergent fiber content makes zoysiagrasses more difficult to mow (Lulli et al., 2012). Thus, to have a high mowing quality, mowers working constantly on zoysiagrasses require more sharpening than mowers working on other grasses (Bevard et al., 2005). Typically, turfgrass mowers are divided into three main groups: rotary mowers, reel mowers, and flail mowers. Rotary mowers cut the grass by hitting it with a revolving single blade and are most effective at mowing tall grass and mulching clippings. However, rotary mowers are not suitable for mowing at low heights and often result in scalping (Munshaw, 2018). Reel mowers instead cut the grass with a scissor-like action using a reel cylinder and a bed knife. Reel mowers perform optimal mowing at a short height (below $2.5 \mathrm{~cm}$ ) and are suitable for tough-to-mow grasses such as zoysiagrass and bermudagrass (Munshaw, 2018). Reel mowers are, thus, usually chosen for golf courses and sports turfs. However, there is a kind of rotary mower that has proven to produce a superior turf quality compared with traditional walk-behind rotary mowers: autonomous mowers (Grossi et al., 2016; Pirchio et al., 2018b). Time and labour saving, no polluting gasses, preventing contact with allergens, energy saving and very low noise emissions are just some of the advantages of using autonomous mowers (Hicks and Hall, 2000; Ragonese and Marx, 2015). Modern autonomous mowers are battery powered and perform lawn mowing without requiring an operator. Unlike walk-behind rotary mowers, autonomous mowers are not designed to collect clippings. Autonomous mowers are, thus, usually programmed to operate every day to produce minimal amounts of small clippings. Through a process called grasscycling (or mulching) the small clippings can be easily integrated into the turfgrass without forming thatch (Brede, 2000). The cutting system of autonomous mowers usually consists of a cutting disc with small pivoting blades (Honda, 2018; Husqvarna, 2018), or a single blade with three or four cutting edges (Robomow, 2018; Zucchetti Centro Sistemi Spa, 2018). Theoretically, autonomous mowers may reach a minimum of $2.0 \mathrm{~cm}$ mowing height. In a recent trial (Pirchio et al., 2018a), a prototype-autonomous mower cutting at a $1.2 \mathrm{~cm}$ mowing height has been tested on a manila grass turf. The authors suggest that the autonomous mower tested in the trial may be a valid alternative to reel mowers at low mowing heights. In scientific literature, no autonomous mower has ever been tested at a low mowing height on an overseeded warm season turfgrass. The trial was carried out to simulate a low-maintenance golf tee, overseeded with cool season turfgrasses, with no pesticide application and with one of the most hard to mow turfgrass species: Zoysia matrella (Turgeon, 2012). The aim of this trial was to compare the performance of different cool season turfgrasses in a polystand with manila grass for a year-round period of two years, mown as a golf tee at $1.0 \mathrm{~cm}$ (Czyzewski and McGraw, 2017) with a prototype-autonomous rotary mower, evaluating their persistence as ground cover, overall quality, turf colour and shoot density.

\section{Materials and methods}

The trial was carried out in the experimental station Rottaia of the Centre for Research on Turfgrass for Environment and Sports (CeRTES), Department of Agriculture Food and Environment,

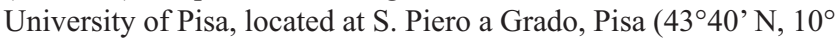
19' E, 6 m. a.s.1.), Italy, from October 2016 to October 2018. A mature stand of manila grass (Zoysia matrella cv Zeon), established on a silty loam soil (Calcaric Fluvisol, 28\% sand, 55\% silt and $17 \%$ clay) with a $\mathrm{pH}$ of 7.8 and $18 \mathrm{~g} \mathrm{~kg}^{-1}$ organic matter, was scalped and aerated with a verticutter on October 2, 2016. A $5 \mathrm{~mm}$ silica-sand top-dressing was carried out afterwards. On October 20, 2016, 11 different cool season turfgrasses and a dwarf white clover (Trifolium repens cv Microclover) were overseeded manually (Table 1) and arranged in a randomised block experimental design with 4 replications. Dwarf clover had been chosen as a control since it does not belong to the Poaceae family. Plots had a 1.5 $\mathrm{m}^{2}(1.0 \times 1.5 \mathrm{~m})$ surface area. To improve seed germination, the entire trial area was covered with Edilfloor Thermofelt geotextile (30 $\mathrm{g} \mathrm{m}^{-2}$ specific weight) for 20 days after seeding and irrigated every day. At sowing date, $50 \mathrm{~kg} \mathrm{ha}^{-1}$ of $\mathrm{N}, 92 \mathrm{~kg} \mathrm{ha}^{-1}$ of $\mathrm{P}$ and 50 $\mathrm{kg} \mathrm{ha}^{-1}$ of $\mathrm{K}$ were distributed.

In 2017 (March, 9; August, 29) and 2018 (March, 6; August, 28), $50 \mathrm{~kg} \mathrm{ha}^{-1}$ of $\mathrm{P}, 100 \mathrm{~kg} \mathrm{ha}^{-1}$ of $\mathrm{N}$ and $50 \mathrm{~kg} \mathrm{ha}^{-1}$ of $\mathrm{K}$ were distributed each time. First mowing was carried out on December 20, 2016, with a rotary mower (Honda mod. HRD 536 C; Honda France manufacturing; Ormes, France) set at $6.0 \mathrm{~cm}$ mowing height. Subsequent mowing was carried out once a week with a reel mower (McLane mod. 20-3.5 RP-7; McLane; Paramount, CA) and mowing height was gradually reduced to $1.0 \mathrm{~cm}$. From February 13, 2017, automatic mowing was performed with an autonomous mower (Husqvarna mod. Automower 310; Husqvarna; Stockholm, Sweden) custom modified to cut from 0.5 to $2.5 \mathrm{~cm}$. Mowing height was set at $1.0 \mathrm{~cm}$ and mowing time was set at $7 \mathrm{~h} \mathrm{~d}^{-1}$.

Every month, from February 2017 to October 2018, the following parameters were visually assessed: i) Ground cover (\%): as the percentage of ground covered by the overseeded species and by manila grass; ii) Weed cover (\%): as the percentage of ground cov-

Table 1. List of species overseeded on manila grass.

\begin{tabular}{|c|c|c|}
\hline Species & Cultivar & $\begin{array}{l}\text { Seed } \\
\text { rates } \\
\left(\mathrm{g} \mathrm{m}^{-2}\right)\end{array}$ \\
\hline Agrostis stolonifera L. & L93 & 5 \\
\hline Festuca arundinacea Schreb. & Essential & 50 \\
\hline Festuca rubra L. ssp. commutata (Thuill.) Nyman & Greenmile & 25 \\
\hline Festuca rubra L. ssp. rubra Gaud. & Heidrun & 25 \\
\hline $\begin{array}{l}\text { Festuca rubra L. ssp. trichophylla } \\
\text { (Ducros ex Gaudin) K. Richt }\end{array}$ & Valdora & 25 \\
\hline Lolium multiflorum Lam. & Axcella & 50 \\
\hline Lolium perenne $\mathrm{L}$. & Berlioz & 50 \\
\hline Lolium perenne L. & Columbine & 50 \\
\hline Poa pratensis $\mathrm{L}$. & Yvette & 15 \\
\hline Poa supina Schard. & Supreme & 15 \\
\hline Poa trivialis $\mathrm{L}$. & Sabrena & 15 \\
\hline Trifolium repens L. & Microclover & 20 \\
\hline
\end{tabular}


ered by weeds; iii) Visual quality: $(1=$ poor; $9=$ excellent $)$, with 6 considered the minimum acceptable level (Morris and Shearman, 2018); iv) Colour: $(1=$ straw brown, $6=$ light green and $9=$ dark green), with 6 considered the minimum acceptable level (Morris and Shearman, 2018).

On May 25, 2017, and on May 16, 2018 one $50 \mathrm{~cm}^{2}$ core sample per plot was collected and shoot density was determined by direct counting with data reported as number of shoots per square centimetre.

Statistical analysis was carried out with a COSTAT 6.400 software (CoHort Software, Monterey, CA, USA). All data were analysed by one-way ANOVA, and an all pairwise Fisher's least significant difference (LSD) test at the probability level of 0.05 .

\section{Results}

\section{Ground cover}

During the first year Lolium entries showed a very high ground cover at the beginning of the trial (from $69 \%$ to $84 \%$ ), but at the end of the summer their ground cover strongly decreased (Table 2), and no differences were found between Lolium perenne cultivars. Poa entries and Festuca arundinacea ground cover also strongly decreased during summer, while Agrostis stolonifera increased its ground cover throughout the summer (from 61\% to $78 \%$ ). Trifolium repens ground cover increased during all the first year (from $36 \%$ to $99 \%$ ) (Table 2). After the spring green up Z. matrella ground cover ranged from $20 \%$ to $57 \%$, filling up the empty spaces formerly covered by the cool season species. Zoysia matrella ground cover progressively increased during summer as most of the cool season species ground cover decreased except for $T$. repens, A. stolonifera, and Festuca rubra trichophylla. Trifolium repens did not allow Z. matrella to expand, as only $1 \%$ of Zoysia remained after the end of the summer (Table 2). At the beginning of the second year of the trial Lolium entries showed a ground cover ranging from $20 \%$ to $41 \%$ (Table 3), but at the end of the trial Lolium entries ground cover was close to $0 \%$. Poa entries had a slightly higher ground cover at the beginning of the second year (ranging from $47 \%$ to $48 \%$ ), but at the end of the trial ground cover was also close to $0 \%$ (Table 3 ).

Festuca arundinacea had a very low ground cover during all the second year, while the ground cover of Festuca rubra cultivars was very high at the beginning of the second year (ranging from $80 \%$ to $86 \%$ ) and decreased during summer. Agrostis stolonifera ground cover also decreased during the summer (from $67 \%$ to $33 \%$ ), showing major competition from manila grass. Trifolium repens ground cover was very high at the beginning of the second year but decreased at the end of the summer. After the green up Zoysia matrella ground cover ranged from $15 \%$ to $89 \%$ and progressively increased since all cool season species decreased their ground cover during summer (Table 3).

At the end of both years Trifolium repens had the highest ground cover, followed by Agrostis stolonifera and by Festuca rubra cultivars (Tables 2 and 3 ).

\section{Visual quality}

During the first year of the trial, turf quality of most cool season species increased from February to September, with the exception of Poa supina, Lolium multiflorum and Festuca arundinacea, since their ground cover was lower than $5 \%$. At the beginning of the trial, only Lolium perenne cultivars and Festuca rubra cultivars had an acceptable quality. Trifolium repens had the lowest quality while Lolium perenne cultivars had the highest (Table 4). At the end of the first year Trifolium repens still had the lowest quality (6.1) while Festuca rubra cultivars and Poa trivialis had the highest quality (from 7.3 to 7.5). At the beginning of the second year of the trial only Festuca rubra cultivars and Lolium perenne cultivars had a good quality (Table 4). At the end of the trial Festuca rubra cultivars had the highest quality (from 7.5 to 7.6) while the lowest quality was achieved by Agrostis stolonifera with a score of 5.6

Table 2. Cool season species and Zoysia matrella ground cover percentages during the first year of the trial (2017) on February 20, April 3 , June 7 and September 2 (in each date total ground cover was $100 \%$, i.e. no bare soil and no weeds).

\begin{tabular}{|c|c|c|c|c|c|c|c|c|c|}
\hline \multirow[t]{2}{*}{ Species } & \multirow[t]{2}{*}{ Cultivar } & \multicolumn{2}{|c|}{ 20-Feb } & \multicolumn{2}{|c|}{ 3-Apr } & \multicolumn{2}{|c|}{ 7-Jun } & \multicolumn{2}{|c|}{ 2-Sep } \\
\hline & & $\begin{array}{c}\text { Cool } \\
\text { species } \\
(\%)\end{array}$ & $\begin{array}{c}\text { Zoysia } \\
\text { matrella* } \\
\text { (\%) }\end{array}$ & $\begin{array}{c}\text { Cool } \\
\text { species } \\
(\%)\end{array}$ & $\begin{array}{c}\text { Zoysia } \\
\text { matrella } \\
(\%)\end{array}$ & $\begin{array}{c}\text { Cool } \\
\text { species } \\
(\%)\end{array}$ & $\begin{array}{c}\text { Zoysia } \\
\text { matrella } \\
(\%)\end{array}$ & $\begin{array}{c}\text { Cool } \\
\text { species } \\
(\%)\end{array}$ & $\begin{array}{c}\text { Zoysia } \\
\text { matrella } \\
\text { (\%) }\end{array}$ \\
\hline Agrostis stolonifera & L93 & 40 & 60 & 62 & 38 & 61 & 39 & 78 & 22 \\
\hline Festuca arundinacea & Essential & 55 & 45 & 45 & 55 & 46 & 54 & 4 & 96 \\
\hline Festuca rubra commutata & Greenmile & 40 & 60 & 57 & 43 & 55 & 45 & 61 & 39 \\
\hline Festuca rubra rubra & Heidrun & 35 & 65 & 61 & 39 & 58 & 42 & 52 & 48 \\
\hline Festuca rubra trichophylla & Valdora & 49 & 51 & 47 & 53 & 51 & 49 & 65 & 35 \\
\hline Lolium multiflorum & Axcella & 69 & 31 & 43 & 57 & 10 & 90 & 0 & 100 \\
\hline Lolium perenne & Berlioz & 81 & 19 & 61 & 39 & 47 & 53 & 11 & 89 \\
\hline Lolium perenne & Columbine & 84 & 16 & 72 & 28 & 52 & 48 & 17 & 83 \\
\hline Poa pratensis & Yvette & 36 & 64 & 47 & 53 & 29 & 71 & 19 & 81 \\
\hline Poa supina & Supreme & 30 & 70 & 44 & 56 & 39 & 61 & 4 & 96 \\
\hline Poa trivialis & Sabrena & 55 & 45 & 80 & 20 & 7 & 93 & 32 & 68 \\
\hline Trifolium repens & Microclover & 36 & 64 & 61 & 39 & 89 & 11 & 99 & 1 \\
\hline LSD 0.05 & & 16 & 19 & 21 & 21 & 18 & 18 & 15 & 15 \\
\hline
\end{tabular}

Means are significantly different at the 0.05 level of probability as determined by Fisher's protected LSD. *Dormant (Zoysia matrella green up started on March 10 ). 
(not acceptable value) and Trifolium repens with a score of 6.4 (acceptable according to the 1-9 scale). The quality of the other cool season species was not evaluated at the end of the trial since their ground cover was lower than 5\% (Table 4).

\section{Colour}

At the beginning of the first year of the trial, the colour of most cool season species was acceptable with the exception of Lolium multiflorum (Table 5). At the end of the first year, the colour of all cool season species evaluated was acceptable. Agrostis stolonifera had the lowest colour score (6.0) and Trifolium repens had the highest (7.3). At the beginning of the second year, only Trifolium repens had a good colour (7.0), while the other cool season species ranged from 5.2 to 6.3 (Table 5). From February to April colour scores of most species decreased. Agrostis stolonifera had the lowest score (5.1) and Poa pratensis had the highest (6.3). At the end of the second year only Agrostis stolonifera had a non-acceptable colour, while Festuca rubra cultivars and Trifolium repens ranged from 6.0 to 7.1 .

\section{Shoot density}

Shoot density during the first year varied from 5.5 to 12.9 shoots $\mathrm{cm}^{-2}$ (Table 6). L. multiflorum and F. arundinacea had the lowest shoot density (5.5 and 6.4 shoots $\mathrm{cm}^{-2}$, respectively) while P. trivialis and F. rubra trichophylla had the highest (12.9 and 12.3 shoots $\mathrm{cm}^{-2}$, respectively). During the second year of the trial shoot density of all species was lower, ranging from 0.4 to 6.7 shoots $\mathrm{cm}^{-2}$ (Table 6). Moreover, during the second year L. multi-

Table 3. Cool season species and Zoysia matrella ground cover percentages during the second year of the trial (2018) on February 9, April 6, June 1 and October 3 (in each date total ground cover was $100 \%$, i.e. no bare soil and no weeds).

\begin{tabular}{|c|c|c|c|c|c|c|c|c|c|}
\hline \multirow[t]{2}{*}{ Species } & \multirow[t]{2}{*}{ Cultivar } & \multicolumn{2}{|c|}{ 9-Feb } & \multicolumn{2}{|c|}{ 6-Apr } & \multicolumn{2}{|c|}{ 1-Jun } & \multicolumn{2}{|c|}{ 3-0ct } \\
\hline & & $\begin{array}{c}\text { Cool } \\
\text { species } \\
(\%)\end{array}$ & $\begin{array}{l}\text { Zoysia } \\
\text { matrella* } \\
\text { (\%) }\end{array}$ & $\begin{array}{c}\text { Cool } \\
\text { species } \\
(\%)\end{array}$ & $\begin{array}{c}\text { Zoysia } \\
\text { matrella } \\
(\%)\end{array}$ & $\begin{array}{c}\text { Cool } \\
\text { species } \\
(\%)\end{array}$ & $\begin{array}{c}\text { Zoysia } \\
\text { matrella } \\
(\%)\end{array}$ & $\begin{array}{c}\text { Cool } \\
\text { species } \\
(\%)\end{array}$ & $\begin{array}{c}\text { Zoysia } \\
\text { matrella } \\
(\%)\end{array}$ \\
\hline Agrostis stolonifera & L93 & 67 & 33 & 66 & 34 & 31 & 69 & 33 & 67 \\
\hline Festuca arundinacea & Essential & 10 & 90 & 11 & 89 & 3 & 97 & 5 & 95 \\
\hline Festuca rubra commutata & Greenmile & 80 & 20 & 79 & 21 & 30 & 70 & 26 & 74 \\
\hline Festuca rubra rubra & Heidrun & 80 & 20 & 79 & 21 & 26 & 74 & 19 & 81 \\
\hline Festuca rubra trichophylla & Valdora & 86 & 14 & 85 & 15 & 35 & 65 & 30 & 70 \\
\hline Lolium multiflorum & Axcella & 20 & 80 & 20 & 80 & 5 & 95 & 0 & 100 \\
\hline Lolium perenne & Berlioz & 35 & 65 & 35 & 65 & 8 & 92 & 3 & 97 \\
\hline Lolium perenne & Columbine & 41 & 59 & 41 & 59 & 10 & 90 & 3 & 97 \\
\hline Poa pratensis & Yvette & 47 & 53 & 45 & 55 & 16 & 84 & 3 & 97 \\
\hline Poa supina & Supreme & 48 & 52 & 40 & 60 & 11 & 89 & 0 & 100 \\
\hline Poa trivialis & Sabrena & 47 & 53 & 45 & 55 & 5 & 95 & 0 & 100 \\
\hline Trifolium repens & Microclover & 91 & 9 & 69 & 31 & 71 & 29 & 55 & 45 \\
\hline LSD 0.05 & & 19 & 20 & 21 & 21 & 11 & 11 & 14 & 14 \\
\hline
\end{tabular}

Means are significantly different at the 0.05 level of probability as determined by Fisher's protected LSD. *Dormant (Zoysia matrella green up started on March 7).

Table 4. Cool season species quality $(1=$ poor, 9 = excellent, $6=$ minimum acceptable level) during the first year (2017) on February 20 , April 3 and September 2 and during the second year (2018) on February 9, April 6 and October 3.

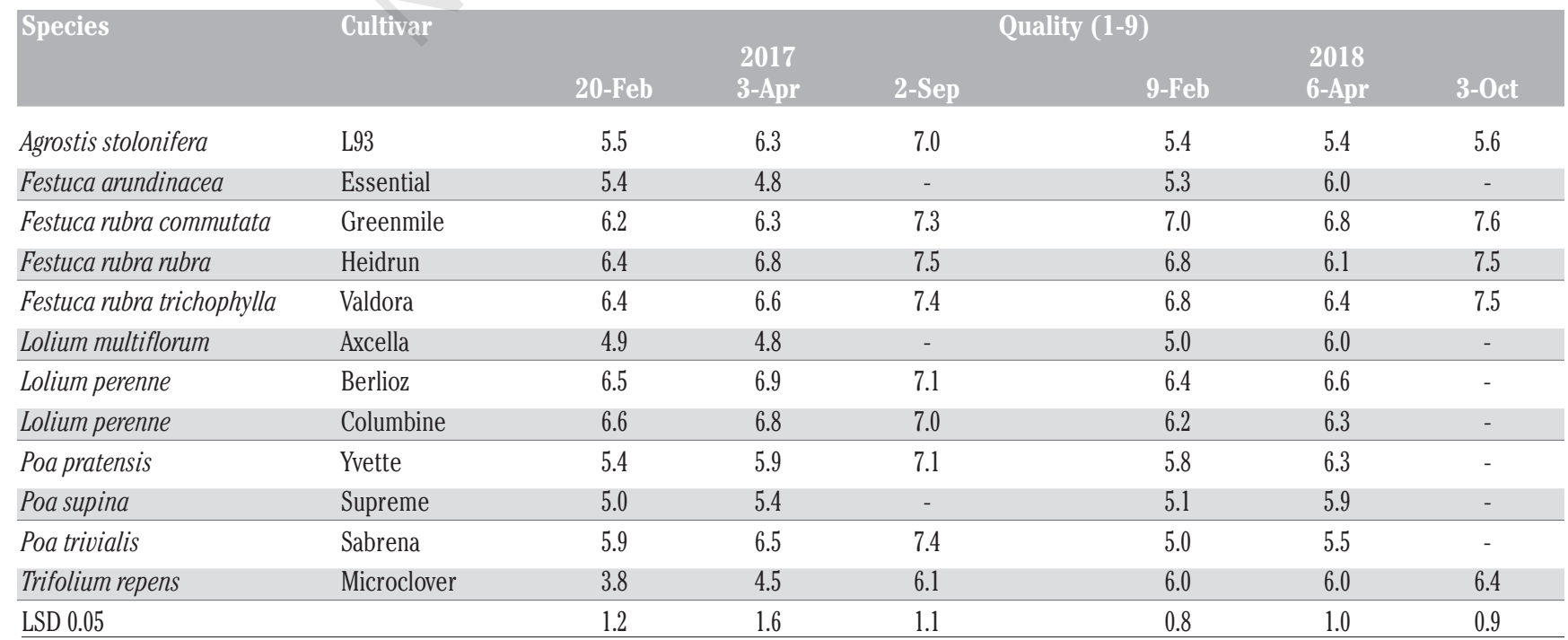

Means are significantly different at the 0.05 level of probability as determined by Fisher's protected LSD. - = not evaluated (Ground cover less than 5\%). 
florum and F. arundinacea had the lowest shoot density (0.4 and 0.6 shoots $\mathrm{cm}^{-2}$, respectively), while the highest shoot density belonged to $F$. rubra commutata ( 6.7 shoots $\left.\mathrm{cm}^{-2}\right)$, A. stolonifera (6.6 shoots $\mathrm{cm}^{-2}$ ) and F. rubra trichophylla $\left(6.6\right.$ shoots $\left.\mathrm{cm}^{-2}\right)$.

\section{Weed cover}

Weed cover percentage resulted lower than $1 \%$ during all the trial period (data not shown) probably due to the extreme competition exerted by manila grass against weeds.

\section{Discussion}

Ground cover percentage of most turf species was lower during the second year of the trial. Moreover, during both years, ground cover percentage of most species decreased at the end of the summer. The trend of the ground cover of Lolium multiflorum was very similar to what Volterrani et al. (2004) had previously reported on bermudagrass. Starting at $69 \%$ ground cover at the beginning of the first year and at $20 \%$ ground cover at the beginning of the second year, at the end of the summer of both years Lolium multiflorum ground cover percentage was $0 \%$. Lolium perenne, L. multiflorum and $P$. supina showed to suffer from the competition exerted by manila grass, although $L$. perenne and $L$. multiflorum are both often chosen to overseed bermudagrass (Cynodon dactylon L.) turfs (Serensits et al., 2011; Aldahir et al., 2015). Festuca rubra sp. cultivars showed to be more persistent in the polystand with manila grass. Festuca rubra sp. cultivars also showed a higher ground cover at the beginning of the second year compared to the other cool season species apart for $T$. repens and A. stolonifera. The species that was less affected by manila grass

Table 5. Cool season species colour $(1=$ poor, 9 = excellent, $6=$ minimum acceptable level $)$ during the first year (2017) on February 20 , April 3 and September 2 and during the second year (2018) on February 9, April 6 and October 3.

\begin{tabular}{|c|c|c|c|c|c|c|c|}
\hline Species & Cultivar & 20-Feb & $\begin{array}{l}2017 \\
3-A p r\end{array}$ & 2-Sep & 9-Feb & $\begin{array}{l}2018 \\
6 \text {-Apr }\end{array}$ & 3-0ct \\
\hline Agrostis stolonifera & L93 & 6.4 & 6.5 & 6.0 & 5.2 & 5.1 & 5.5 \\
\hline Festuca arundinacea & Essential & 6.3 & 6.6 & - & 6.0 & 6.0 & - \\
\hline Festuca rubra commutata & Greenmile & 6.6 & 6.8 & 6.7 & 6.2 & 5.8 & 6.7 \\
\hline Festuca rubra rubra & Heidrun & 6.8 & 6.6 & 6.6 & 5.8 & 5.5 & 6.6 \\
\hline Festuca rubra trichophylla & Valdora & 6.8 & 6.9 & 6.8 & 5.7 & 5.3 & 6.0 \\
\hline Lolium multiflorum & Axcella & 4.9 & 5.9 & - & 6.0 & 6.0 & - \\
\hline Lolium perenne & Berlioz & 5.8 & 6.8 & 6.9 & 5.8 & 5.5 & - \\
\hline Lolium perenne & Columbine & 6.1 & 6.6 & 6.8 & 5.7 & 5.8 & - \\
\hline Poa pratensis & Yvette & 6.9 & 6.8 & 6.9 & 6.3 & 6.3 & - \\
\hline Poa supina & Supreme & 6.5 & 6.6 & - & 6.2 & 6.0 & - \\
\hline Poa trivialis & Sabrena & 6.8 & 7.0 & 6.8 & 6.0 & 6.0 & - \\
\hline Trifolium repens & Microclover & 6.1 & 7.0 & 7.3 & 7.0 & 6.0 & 7.1 \\
\hline LSD 0.05 & & 0.5 & 0.7 & 0.6 & 0.4 & 0.5 & 0.7 \\
\hline
\end{tabular}

Means are significantly different at the 0.05 level of probability as determined by Fisher's protected LSD. - = not evaluated (Ground cover less than 5\%).

Table 6. Cool season species shoot density $\left(\right.$ shoots $\left.\mathrm{cm}^{-2}\right)$ during the first year of the trial on May 23, 2017 and the second year of the trial on May 16, 2018.

\begin{tabular}{|c|c|c|c|}
\hline Species & Cultivar & $\begin{array}{c}\text { 23-May } 2017 \\
\text { Shoot density }\left(\mathrm{no}^{\mathrm{cm}} \mathrm{cm}^{-2}\right)\end{array}$ & $\begin{array}{c}\text { 16-May } 2018 \\
\left.\text { Shoot density }\left(\text { no. }^{-2}\right)^{-2}\right)\end{array}$ \\
\hline Agrostis stolonifera & L93 & 9.2 & 6.6 \\
\hline Festuca arundinacea & Essential & 6.4 & 0.6 \\
\hline Festuca rubra commutata & Greenmile & 11.6 & 6.7 \\
\hline Festuca rubra rubra & Heidrun & 10.9 & 6.0 \\
\hline Festuca rubra trichophylla & Valdora & 12.3 & 6.6 \\
\hline Lolium multiflorum & Axcella & 5.5 & 0.4 \\
\hline Lolium perenne & Columbine & 9.2 & 2.4 \\
\hline Lolium perenne & Berlioz & 11.4 & 3.2 \\
\hline Poa pratensis & Yvette & 9.5 & 2.1 \\
\hline Poa supina & Supreme & 10.7 & 2.1 \\
\hline Poa trivialis & Sabrena & 12.9 & 3.0 \\
\hline Trifolium repens & Microclover & $6.0^{*}$ & $3.4^{*}$ \\
\hline LSD 0.05 & & 4.3 & 1.8 \\
\hline
\end{tabular}

Means are significantly different at the 0.05 level of probability as determined by Fisher's protected LSD. *Stalks. 
competition was the dwarf clover, especially at the end of the first year when its ground cover was $99 \%$. Despite this, at the end of the second year manila grass reached $45 \%$ of ground cover. Dwarf clover proved to be too competitive even for manila grass, probably due to its high seed rate establishment (McCurdy et al., 2013) associated with the low fertilisation program adopted. Dwarf clover quality was initially quite low, however it increased and remained acceptable during the second year. The best quality was achieved by Festuca rubra sp. cultivars and Lolium perenne cultivars. Shoot density of all cool season species was higher at the end of the first year rather than at the end of the second year. This was probably due to the very strong competition offered by manila grass that progressively managed to expand against the cool season species. The very low shoot density of Lolium multiflorum and Festuca arundinacea at the end of the second year showed that these species did not adapt to withstand manila grass competition. Although other studies have shown poor summer recovery of zoysiagrass after overseeding (Razmjoo et al., 1996; Zhang et al., 2008), our results highlighted that after two years only dwarf clover caused an incomplete recovery of manila grass.

\section{Conclusions}

Overseeding has become a standard industry practice for golf courses and athletic fields receiving significant traffic during the winter season in the southern United States (Fontanier and Steinke, 2017). In order to have a low-input turf management, a polystand may be a more sustainable practice since overseeding is performed only at the beginning. In our study, after a two-year trial period, the best quality was achieved by Festuca rubra sp. cultivars. In many cases quality increased after manila grass green up because the combination of cool season and warm season species produced a finer leaf texture and a higher shoot density. Moreover, manila grass ground cover recovery was satisficing, even if during the first year it appeared quite slow, probably because of the severe scalping and the thick sand top-dressing. These encouraging results show that it's possible to obtain a useful and sustainable intercropping between cool season turf species and manila grass for a twoyear period. A polystand of manila grass with some cultivars of Festuca rubra ssp. could be suitable for a low-input management of a golf tee, looking forward to the reduction of chemical inputs allowed on turfs by the European regulations.

\section{References}

Aldahir PCF, McElroy JS, Flessner ML, Baird JH, Magni S, Grossi N, Volterrani M, 2015. Cultural and chemical practices for quality improvement of overseeded bermudagrass (Cynodon dactlyon (L.) Pers. x C. transvaalensis Burtt-Davey), and annual bluegrass (Poa annua L.) suppression. J. Environ. Hort. 33:7-14.

Anderson SJ, 2000. Taxonomy of Zoysia (Poaceae): morphological and molecular variation. PhD Diss. Texas A\&M Univ., College Station, TX, USA.

Bevard D, Foy J, Lowe T, White B, 2005. Alternative grasses: Panacea or problem? U.S. Golf Assn. USGA Green Sect. Rec. 43:26-8.

Brede D, 2000. Turfgrass maintenance reduction handbook: Sports, lawns, and golf. Sleeping Bear Press, Chelsea, MI, USA.

Carrow RN, Duncan RR, 1988. Salt-affected turfgrass sites. Assessment and management. Ann Arbor Press, MI, USA.
Czyzewski BD, McGraw BA, 2017. Mowing height influences listronotus maculicollis (Coleoptera: Curculionidae) oviposition behavior and mechanical removal from golf course putting greens, but not larval development. J. Econ. Entomol. 110: 2165-71.

Engelke MC, Colbaugh PF, Reinert JA, Marcum KB, White RH, Ruemmele BA, Anderson SJ, 2002a. Registration of 'Diamond' zoysiagrass. Crop Sci. 42:304-5.

Engelke MC, Reinert JA, Colbaugh PF, White RH, Ruemmele BA, Marcum KB, Anderson SJ, 2002b. Registration of 'Cavalier' zoysiagrass. Crop Sci. 42:302-3.

Fontanier C, Steinke K, 2017. Performance of annual and perennial ryegrass mixtures for winter overseeding into three warm season turfgrass species. Intl. Turfgrass Soc. Res. J. 13:305-11.

Grossi N, Fontanelli M, Garramone E, Peruzzi A, Raffaelli M, Pirchio M, Martelloni L, Frasconi C, Caturegli L, Gaetani M, Magni S, McElroy JS, Volterrani M, 2016. Autonomous mower saves energy and improves quality of tall fescue lawn. Hort. Technology. 26:825-30.

Gullino ML, Mocioni M, Zanin G, Alma A, 2000. La difesa dei tappeti erbosi. Ed. L'Informatore Agrario s.r.l., Verona, Italy.

Harivandi MA, 1991. Effluent water for turfgrass irrigation. Univ. of California Coop. Ext. Leaflet 21500. Div. of Agric. Nat. Resources, Oakland, CA, USA.

Hicks RW, Hall EL, 2000. Survey of robot lawn mowers. pp 262269 in Proc. SPIE 4197. Intelligent Robots and Computer Vision XIX: Algorithms, Techniques, and Active Vision. Boston, MA, USA.

Honda, 2018. Miimo at a glance. Available from: https://www. honda.co.uk/lawn-and-garden/products/ miimo/overview.html Accessed: 20 June 2018.

Husqvarna, 2018. Husqvarna automower 105/310/315/320/ 330X/420/430X/450X operator's manual. Available from: http:/www.husqvarna.com/uk/support/manuals-downloads/ Accessed: 20 June 2018.

Lulli F, Volterrani M, Grossi N, Armeni R, Stefanini S, Guglielminetti L, 2012. Physiological and morphological factors influencing wear resistance and recovery in $\mathrm{C} 3$ and $\mathrm{C} 4$ turfgrass species. Funct. Plant Biol. 39: 214-21.

Magni S, Pompeiano A, Gaetani M, Caturegli L, Grossi N, Minelli A, Volterrani M, 2017. Zoysiagrass (Zoysia spp.Willd.) for european lawns: A review. Ital. J. Agron. 12:395-402.

McCurdy JD, McElroy JS, Guertal EA, 2013. White clover (Trifolium repens) establishment within dormant bermudagrass turf: Cultural considerations, establishment timing, seeding rate, and cool-season companion grass species. HortSci. 48:1556-61.

Morris KN, 2016. Evaluation of warm season grasses for putting greens. USGA Turfgrass Environ. Res. Summary 241-3.

Morris KN, Shearman RC, 2018. NTEP turfgrass evaluation guidelines. Available from: http://www.ntep.org/pdf/ratings Accessed: 20 June 2018.

Munshaw G, 2018. Mowing your Kentucky lawn. 2013. Available from: http://www2.ca.uky.edu/agcomm/pubs/agr/agr209/ agr209.pdf Accessed: 20 June 2018.

Patton AJ, Schwartz BM, Kenworthy KE, 2017. Zoysiagrass (Zoysia spp.) history, utilization, and improvement in the United States: a review. Crop Sci. 57:S37-72.

Pirchio M, Fontanelli M, Frasconi C, Martelloni L, Raffaelli M, Peruzzi A, Caturegli L, Gaetani M, Magni S, Volterrani M, Grossi N, 2018a. Autonomous rotary mower vs. ordinary reel mower: effects of cutting height and nitrogen rate on manila grass turf quality. HortTechn. 28:509-15. 
Pirchio M, Fontanelli M, Frasconi C, Martelloni L, Raffaelli M, Peruzzi A, Gaetani M, Magni S, Caturegli L, Volterrani M, Grossi N, 2018b. Autonomous mower vs. rotary mower: Effects on turf quality and weed control in tall fescue lawn. Agronomy (Basel) 8:15.

Pompeiano A, Grossi N, Guglielminetti L, Volterrani M, 2014. Winter colour retention and spring green up of zoysiagrass genotypes in southern Europe. Eur. J. Hort. Sci. 79:158-66.

Pompeiano A, Grossi N, Volterrani M, 2012. Vegetative establishment rate and stolon growth characteristics of 10 zoysiagrasses in southern Europe. HortTechn. 22:114-20.

Ragonese A, Marx J, 2015. The applications of sensor technology in the design of the autonomous robotic lawn mower, Paper No. 5094. 15th Annu. Freshman Eng. Conf., Pittsburgh, PA, USA.

Razmjoo K, Imada T, Kaneko S, 1996. Overseeding manila grass [Zoysia matrella (L.) Merr.] with cool-season turfgrasses. J. Turfgrass Manage. 1:43-52.

Robomow, 2018. Choose your best team player. Available from: http://robomow.com/en-GB/product-category/mowers/ Accessed: 20 June 2018.

Serensits T, Cutulle M, Jeffrey JF, 2011. Persistence of overseeded cool-season grasses in Bermudagrass Turf. Intl. J. Agron. 2011:ID496892.
Turgeon AJ, 2012. Turfgrass management. Prentice Hall, Upper Saddle River, NJ, USA.

Volterrani M, Gaetani M, Grossi N, Lulli F, Magni S, 2003. Warm-season turfgrass overseeding. 11 pp. In National Turfgrass Foundation Annual Conference, Southport, GB.

Volterrani M, Gaetani M, Magni S, Miele S, 2004. Bermudagrass autumn overseeding with annual ryegrass. Acta Hortic. 661:353-6.

Volterrani M, Grossi N, Pardini G, Miele S, Gaetani M, Magni S, 1997. Warm season turfgrass adaptation in Italy. Int. Turfgrass Soc. Res. J. 8:1344-54.

Whereley BG, Skulkaew P, Chandra A, Genovesi AD, Engelke MC, 2011. Low-input performance of zoysiagrass (Zoysia spp.) cultivars maintained under dense tree shade. HortSci. 46:1033-7.

Zhang JM, Luo J, Zhang J, Lin SS, Mo SX, Lu LJ, 2008. Winter overseeding zoysiagrass sports turf with cool-season turfgrasses in southern China. Acta Hort. 783:85-96.

Zucchetti Centro Sistemi Spa, 2018. Ambrogio robot. Available from: http:/www.ambrogiorobot.com/en/ambrogiorobot Accessed: 20 June 2018. 